\title{
PENGEMBANGAN WARISAN BUDAYA TRADISIONAL MENUJU EKOWISATA DUSUN GIYANTI WONOSOBO
}

\author{
Yenny Puspitawati ${ }^{1}$, Atiqa Sabardila ${ }^{2}$ \\ ${ }^{1,2}$ Sekolah Pascasarjana, Universitas Muhammadiyah Surakarta, Indonesia
}

DOI: 10.23917/humaniora.v22i1.11364

Submit: 3 Juli 2020. Revisi: 12 Januari 2021. Diterima: 18 Januari 2021.

Available Online: 27 Januari 2021. Periode Terbit: Februari 2021.

\begin{tabular}{ll}
\hline Keywords & Abstract \\
\hline ecotourism, & This study aims to (1) describe the model development of Giyanti \\
tourism model & village's traditional cultural heritage, and (2) how it elaborates the \\
development, & community and the government in developing the ecotourism of Giyanti \\
wonosobo & Hamlet. This research is a qualitative research. Methods of the data \\
& collection in the field is by using observation techniques, interviews, \\
and documentation. The collected data were then analyzed by \\
Corresponding & describing the results of the study in detail and systematic. Then, the \\
Author & results are presented informally, namely the formulation with ordinary \\
Yenny Puspitawati & words in the form of narrative texts. In this study, it is argued that the \\
Universitas & development of culture towards the ecotourism of the Giyanti village \\
Muhammadiyah & was wrapped in the Community Based Tourism model, which was able \\
Surakarta & to elevate the culture, social, economy of the local community. \\
Indonesia & However, full participation from the community is not enough if there \\
Email: & is no good colaboration with the government. Therefore, there must be \\
yennypuspitawati24@ a & a good colaboration between the community and the government as the \\
gmail.com & organizer of the ecotourism in the village of Giyanti, Wonosobo \\
Telp: - & Regency.
\end{tabular}

\begin{tabular}{ll}
\hline Kata Kunci & Abstrak \\
\hline ekowisata, & Penelitian ini bertujuan untuk (1) mendeskripsikan model pengem- \\
pengembangan model & bangan warisan budaya tradisional Dusun Giyanti, serta (2) memapar- \\
wonosobo & kan kolaborasi yang terjadi antara masyarakat dengan pemerintah da- \\
& lam mengembangkan ekowisata Dusun Giyanti. Penelitian ini merupa- \\
& kan penelitian kualitatif. Metode pengumpulan data di lapangan, \\
& menggunakan teknik observasi, wawancara, dan dokumentasi. Data \\
& yang telah terkumpul kemudian dianalisis secara deskriptif dengan \\
& menguraikan hasil penelitian secara terperinci dan sistematis. Selanjut- \\
& nya, hasilnya disajikan secara informal, yaitu perumusan dengan kata- \\
& kata biasa dalam bentuk teks naratif. Dalam penelitian ini ditemukan \\
& bahwa pengembangan budaya menuju ekowista Dusun Giyanti terbalut \\
& dalam model Community Based Tourism yang dengan model ini mampu \\
& mengangkat budaya, sosial, dan ekonomi masyarakat setempat. Akan \\
& tetapi, partisipasi penuh dari masyarakat tidaklah cukup jika tidak ada \\
& kolaborasi yang baik dengan pemerintah. Oleh karena itu, harus ada \\
& elaborasi yang baik antara masyarakat dan pemerintah sebagai penye- \\
& lenggara ekowisata dusun Giyanti, Kabupaten Wonosobo. \\
\hline
\end{tabular}

\section{PENDAHULUAN}

Budaya yang diwariskan secara turun-temurun dan dilestarikan dari generasi ke generasi merupakan wujud peninggalan yang sangat berharga dan merupakan 
jati diri suatu masyarakat. Secara definitif budaya memiliki pengertian yang cukup luas. E.B Taylor (Ratna, 2010:153) mendefinisikan kebudayaan sebagai hasil aktivitas manusia, baik konkret maupun abstrak, baik dengan tujuan positif maupun negatif.

Dusun Giyanti yang terletak di daerah pegunungan, tepatnya di Desa Kadipaten, Kecamatan Selomerto, Kabupaten Wonosobo menjadi salah satu pusat pelestarian budaya warisan nenek moyang asal daerah ini. Warisan asli yang sampai hari ini masih terus dijaga kelestariannya ialah tari Lengger dan Nyadran Tenongan.

Secara umum, fenomena kebudayaan di era ini tampaknya sangat beragam. Munculnya budaya pop tak lantas menjadikan masyarakat di Dusun Giyanti, termasuk generasi muda, meninggalkan warisan budaya yang mereka miliki. Dusun kecil yang menjadi sentra budaya, khususnya tari Lengger asli Wonosobo secara berangsur mengembangkan budaya tradisional tersebut, bahkan mampu merambah pada pasar yang lebih luas penikmatnya. Tak hanya itu, pegiat budaya di dusun tersebut mampu mengolaborasikan sumber daya alam dan sumber daya manusianya yang kemudian disajikan pada suatu konsep ekowisata.

Pengembangan warisan budaya tradisonal menuju ekowisata yang dikembangkan di Dusun Giyanti merupakan suatu upaya pemberdayaan. Adanya pemberdayaan menandakan bahwa keadaan masyarakat dan alamnya sudah cukup mapan dalam hal nilai dan identitas. Roberts dan Hall (dalam Chuang, 2010) menyungkapkan bahwa dalam pariwisata pedesaan, harus ada karakteristik khusus yang dapat berupa budaya tradisional, budaya pertanian, pemandangan alam, dan gaya hidup yang sederhana. Hadirnya ekowisata Dusun Giyanti diharapkan mampu untuk mengobati rindu akan susana khas pedesaan serta memunculkan kembali kecintaan masyarakat dengan warisan budaya nenek moyang.

Konsep ekowisata yang merupakan pariwisata umum diuntungkan dengan masyarakat yang berperan aktif dalam mengembangkan seluruh potensi yang ada. Keseriusan masyarakat Giyanti dalam melestarikan dan mengembangkan budaya tradisional menuju ekowisata ini cukup tergambarkan dengan banyaknya wisatawan yang datang berkunjung. Daya tarik yang mampu memikat wisatawan ialah eloknya konsep yang merupakan perpaduan antara wisata tradisional, perayaan budaya, dan edukasi. Konsep semacam ini cukup merepresentasikan pariwisata di Kabupaten Wonosobo yang sarat akan budaya dan alam. Dengan adanya konsep ini, dari lapisan masyarakat terkecil, secara tidak langsung dapat menjadi bagian dalam pengelolaan dan pengembangan wisata bersinergi dengan pemerintah daerah. Hal ini dimaksudkan demi memaksimalkan pengelolaan pariwisata. Strategi ini, dalam khasanah pariwisata disebut dengan community based tourism (CBT). Kendati demikian, hal tersebut rupanya belum menjadi fokus serius bagi pemerintah.

Spillane (1991:133) berpendapat bahwa peran pemerintah dalam mengembangkan pariwisata adalah menyediakan insfrastruktur, memperluas berbagai 
bentuk fasilitas, kegiatan koordinasi antara aparatur pemerintah dengan pihak swasta, pengaturan, dan promosi umum ke luar negeri. Infrastuktur yang seharusnya menjadi salah satu komponen pendukung orbitasi wisata nyatanya belum dibangun secara maksimal. Hal ini tentu sedikit banyak mempengaruhi kesan bagi wisatawan yang berkunjung, terlebih ketika harus melewati jalanan yang kurang bagus. Selain itu, koordinasi pun dirasa belum mencapai titik temu. Hal ini berbeda dengan ketersediaan fasilitas serta promosi wisata yang memang sudah ramai digalakan. Oleh karena itu, dalam penelitian ini dilakukan studi kritis terhadap kolaborasi antara masyarakat dan pemerintah dalam pengembangan warisan budaya tradisional menuju ekowisata Dusun Giyanti.

Penelitian terkait diantaranya Tanaya dan Iwan (2014) yang meneliti potensi pengembangan ekowisata berbasis masyarakat di kawasan Rawa Pening, Kabupaten Semarang. Ridlwan (2017) meneliti model pengembangan ekowisata dalam upaya pemberdayaan masyarakat lokal. Sugiarta dan Agung (2016) meneliti potensi ekowisata dan respon masyarakat Desa Penijnoan, Kecamatan Tembuku. Mukhlisi (2017) meneliti potensi pengembangan ekowisata mangrove di Kampung Tanjung Batu, Kecamatan Pulau Derawan, Kabupaten Berau. Hijriati dan Rina (2014) meneliti pengaruh ekowisata berbasis masyarakat terhadap perubahan kondisi ekologi, sosial dan ekonomi di Kampung Batusuhunan, Sukabumi. Herman dan Bambang (2017) meneliti potensi ekowisata dan kesejahteraan masyarakat. Aulia dan Luchman (2017) meneliti pengembangan potensi ekowisata Sungai Pekalen Atas, Desa Ranu Gedang, Kecamatan Tiris, Kabupaten Probolinggo. Akbar (2019) meneliti Wisuda Lengger Giyanti sebagai daya tarik wisata di Kabupaten Wonosobo.

Penetitian ini bertujuan untuk mendeskripsikan model pengembangan warisan budaya tradisional Dusun Giyanti serta bagaimana kolaborasi yang terjadi antara unsur-unsur terkait, yaitu antarmanusia, dalam hal ini masyarakat dengan pemerintah dalam mengembangkan ekowisata Dusun Giyanti.

\section{METODE}

Dalam penelitian budaya, metode lebih banyak berbicara mengenai langkahlangkah operasional (Endraswara, 2006:5). Penelitian ini termasuk dalam penelitian kualitatif. Penelitian budaya mayoritas dilakukan langsung di lapangan. Data lapangan merupakan sumber objek kultural dengan memanfaatkan berbagai sarana yang sudah dipersiapkam sebelumnya. Dalam aplikasinya, peneliti dapat secara bebas menggali berbagai informasi berkaitan dengan data yang diperlukan dalam penelitian. Sekanjutnya, untuk dapat menggali informasi dengan baik, maka pada pengumpulan data menggunakan teknik observasi yang dilanjutkan dengan wawancara serta dokumentasi. Dalam teknik observasi yang terpenting adalah pengamat serta informan sebagai pemberi informasi. Dalam penelitian ini observasi dilakukan secara langsung di Dusun Giyanti, Desa Kadipaten, Kecamatan Selomerto, Kabupaten Wonsobo. 
Sebagai bentuk tindak lanjut dari teknik observasi, teknik selanjutnya yang digunakan ialah wawancara. Ratna (2010:222) menjelaskan bahwa teknik wawancara ialah cara-cara memperoleh data dengan berhadapan langsung dan bercakap-cakap, baik antara individu dengan individu maupun individu dengan kelompok. Untuk menentukan narasumber wawancara, digunakan metode purposive sampling sebagai upaya untuk pengambilan sampling secara langsung kepada narasumber yang dituju. Dalam penelitian ini, yang diwawancarai secara langsung orang yang menjadi pelaku sejarah dalam pengelolaan dan pengembangan kebudayaan Dusun Giyanti. Berkaitan dengan keabsahan data, informasi yang disampaikan oleh pelaku sejarah langsung akan lebih relefan serta mampu dipertanggungjawabkan kebenarannya. Selanjutnya, sebagai pendukung observasi dan wawancara, peneliti melakukan dokumentasi sebagai bentuk bukti untuk memperkuat penelitian.

Data yang telah terkumpul kemudian dianalisis secara kualitatif dengan menguraikan hasil penelitian secara rinci dan sistematis. Selanjutnya, hasilnya disajikan secara informal, yaitu perumusan dengan kata-kata biasa (Sudaryanto, 1993:145) dalam bentuk teks naratif.

\section{HASIL}

Bentuk geografis wilayah Kabupaten Wonosobo yang berupa pegunungan menyimpan potensi wisata alam yang sangat banyak. Selain itu, beberapa warisan budaya pun cukup melambungkan nama kabupaten ini. Warisan budaya merupakan latar belakang masyarakat yang tidak dapat diabaikan (Puguh, 2017:49; Hidayah et al, 2017) Dieng Culture Festival menjadi satu proyek tahunan yang cukup tersohor dalam pelestarian budaya sekaligus promosi wisata. Tari Lengger, tempe kemul, mie ongklok, carica, purwaceng, berbagai gunung dan bukit, serta objek wisata alam lainnya menjadi primadona yang sejak dahulu sudah berhasil menggiring wisatawan untuk mengunjungi Wonosobo.

Pengelolaan warisan budaya merupakan satu langkah yang perlu dilakukan dalam rangka pelestarian serta pengembangan potensi yang ada di dalamnya. Untuk mendukung potensi pariwisata di Wonosobo, masyarakat di Dusun Giyanti telah berhasil mengelola serta mengembangkan budaya tradisional dengan konsep ekowisata. Dowling (dalam Hill \& Gale, 2009) menyatakan bahwa ekowisata dapat dilihat berdasarkan keterkaitannya dengan 5 elemen inti, yaitu bersifat alami, berkelanjutan secara ekologis, lingkungannya bersifat edukatif, menguntungkan masyarakat lokal, dan menciptakan kepuasan wisatawan. Selain untuk mengembangkan potensi, ekowisata ini juga termasuk dalam pelestarian warisan budaya leluhur. Hal lain yang menjadi menarik ialah di zaman yang serba modern ini, pemberdayaan masyarakat berhasil dilakukan dengan kooperatif. Pemberdayaan yang dilakukan, baik secara individu maupun kelompok, berhasil tercipta di Dusun Giyanti tanpa memandang latar belakang usia, status sosial, bahkan keyakinan. 
Seluruh komponen masyarakat yang terlibat dalam pengelolaan serta pembangan warisan budaya tradisional dapat diandalkan untuk menuju ekowisata. Suatu abstraksi yang menjadi konkret dalam pengembangan wisata ini ialah dengan menyajikan sesuatu yang dewasa ini menjadi kebutuhan hidup manusia. Sajian baru yang menjadi daya tarik dan kekhasan wisata Dusun Giyanti ini ialah dengan menyajikan pertunjukan sandra tari Lengger yang diiringi instrumen gamelan, ting (lentera), dekorasi dan kostum, pernak-pernik khas Jawa serta aroma kuliner tradisional. Secara terstruktur, acara tersebut dilaksanakan setiap hari Sabtu malam.

Selain konsep ekonomi dan budaya lokal, hal lain yang ditawarkan ialah dengan memanjakan pengunjung dengan dijajakannya aneka kuliner tradisional. Semua orang yang bertugas (pengelola, pegiat seni, dan penjual makanan) mengenakan pakaian tradisional. Ketika membeli makanan pun harus menukarkan uang dengan benggol sebagai alat tukar yang setara dengan uang. Sepanjang waktu, pengunjung akan semakin larut dengan alunan musik tradisional yang digaungkan. Selain itu, pengunjung dapat pula menyaksikan secara langsung pertunjukan Tari Lengger sebagai kesenian tari khas Wonosobo. Kegiatan tersebut tidak hanya dilakasanakan ketika siang hari sehingga sebagai instrumen pendukung suasana Jawa zaman dahulu, maka digunakanlah lentera atau disebut juga dengan istilah ting sebagai penerangnya. Untuk memberikan nama sebagai identias, maka konsep yang demikian kemudian oleh masyarakat dinamai dengan "Pasar Ting".

Pasar Ting hadir di tengah masyarakat yang haus akan budaya tradisional. Meskipun mengkhususkan budaya Jawa, pengunjung Pasar Ting berasal dari berbagai kalangan dan daerah. Berdasarkan hasil observasi dan wawancara yang dilakukan dengan Bapak Dwi Pranyoto yang merupakan seniman dan budayawan asal Dusun Giyanti, secara statistik dapat digambarkan bahwa pengunjung Pasar Ting ialah sebagai berikut.

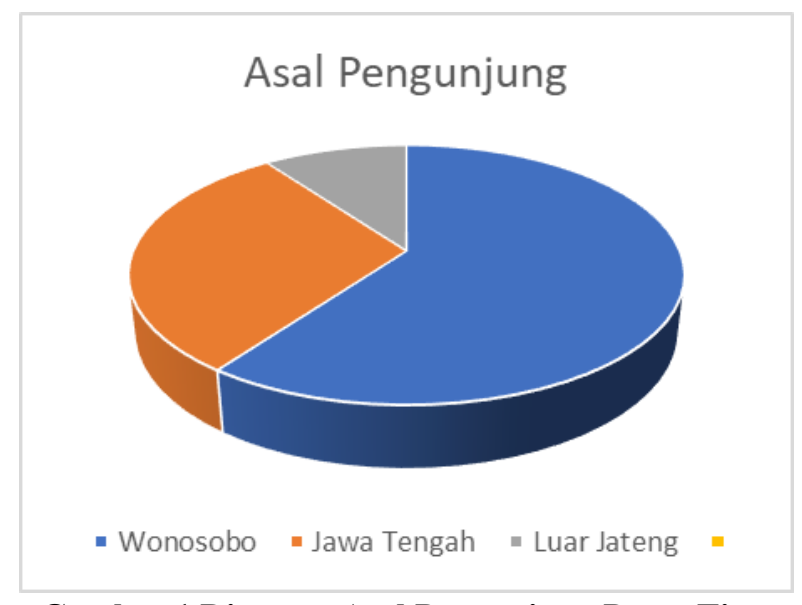

Gambar 1 Diagram Asal Pengunjung Pasar Ting 
Tidak hanya berhenti di sini, masyarakat Dusun Giyanti terus berupaya mengembangkan model ekowisata dengan menambahkan serangkaian konsep live in dan outbond. Live in merupakan suatu bentuk kegiatan yang dirancang sedemikian rupa sehingga memungkinkan individu untuk berinteraksi dengan masyarakat yang berbeda status sosial ekonomi budaya dalam kehidupan nyata. Adapun outbond adalah strategi belajar di alam terbuka dengan tujuan untuk menumbuhkan nilai positif terhadap suatu hal. Pengelola memberikan pilihan berupa paket dalam model pengembangan ekowisata ini. Dalam seragkaian kegiatan live in, secara umum, pengunjung mendapatkan fasilitas belajar kesenian di sanggar tari, kemudian mereka ikut dalam segala kegiatan yang dilakukan oleh masyarakat tempat dimana mereka tinggal. Pada kegiatan outbond, konsep yang ditawarkan ialah outbond lumpur. Hal ini dimaksudkan juga dalam rangka mengenalkan masyarakat khususnya generasi muda zaman sekarang untuk bermain dengan terjun langsung di area persawahan.

Pengembangan pariwisata yang demikian disebut dengan Community Based Tourism. Denga model pengembangan CBT, masyarakat lokal sekitar destinasi wisata dapat menjadi pelaku sekaligus penikmat dalam managemen pariwisata. Peran masyarakat dalam konsep CBT ini sangat penting bagi keberlangsungan pariwisata, peran masyarakat adalah sebagai pelaku, penerima manfaat, serta sebagai pembuat kebijakan. Pengelolaan yang sedemikian rupa semakin menjadi daya tarik masyarakat luas, bahkan hingga ke manca negara.

\section{PEMBAHASAN}

Untuk dapat mencapai keberhasilan dalam pengembangan warisan budaya tradisional menuju ekowisata Dusun Giyanti, diperlukan kolaborasi antara pihak terkait. Berdasarkan Peraturan Menteri Dalam Negeri Nomor 33 Tahun 2009 tentang Pedoman Pengembangan Ekowisata di Daerah Pasal 1 poin 6 yang menyebutkan bahwa "Pelaku ekowisata adalah pemerintah, pemerintah daerah, dunia usaha, dan masyarakat yang bergerak di bidang wisata". Selaras dengan peraturan tersebut, di Kabupaten Wonosobo, Dinas Pariwisata dan Kebudayaan menjadi penting adanya karena sebagai salah satu komponen untuk menggerakkan perekonomian daerah dan di sisi yang lain sebagai akselerator terhadap pelestarian, pengembangan, dan pemanfaatan kebudayaan, baik yang berbentuk tradisi, budaya maupun kesenian.

Berangkat dari skrup kecil, masyarakat setempat berfungsi sebagai basis massa yang menggiatkan pengembangan budaya tradisional menuju ekowisata. Secara praksis dalam beragai kegiatan, seluruh masyarakat di Dusun Giyanti tanpa memandang status sosial, agama, ataupun pendidikan terlibat aktif dalam menyukseskan ekowisata di dusun tersebut. Berdasarkan dari hasil wawancara disebutkan bahwa mayoritas masyarakat Dusun Giyanti bisa menari tarian Jawa. Kelompok-kelompok pegiat seni melalui sanggarnya pun turut hadir dalam rangka mewadahi dan melestarikan budaya. 
Dukungan yang diberikan oleh pemerintah dapat berupa pendampingan, kebijakan yang pro terhadap sektor pariwisata, pembangunan infrastruktur yang memadai, penyediaan fasilitas umum, serta promosi wisata. Dengan segala keterbatasan, pemerintah desa sudah turut andil dalam penembangan ekowisata ini. Ini ditunjukkan dengan adanya penyediaan dana yang diberikan pada saat menyelenggarakan festival budaya Nyadran Tenongan. Karena ekowisata merupakan konsep wisata masal sehingga diperlukan juga payung yang lebih besar untuk menaunginya.

Pemerintah daerah sebagai pemegang otorias tertinggi di tingkat kabupaten tampaknya belum mampu untuk mengambil peran secara maksimal. Infrastruktur menuju lokasi ekowisata Dusun Giyanti yang kurang memadai mengimplikasikan bahwa pemerintah setempat kurang memperhatikan fasilitas. Diakui atau tidak, infrastruktur merupakan komponen utama yang dapat mendukung orbitasi pariwisata.

Selain dari hal tersebut, sebenarnya pemerintah setempat sudah menggalakkan program-program yang dapat mendukung pariwisata di Wonosobo. Akan tetapi, dikarenakan tidak matangnya koordinasi, maka berimbas pada tidak adanya bentuk tindak lanjut dari pemerintah dalam mengawal program-program tersebut. Hal ini menyebabkan tidak tuntasnya pemerintah dalam mengembangkan segala potensi yang ada. Oleh sebab itu, ke depan diharapkan antar semua unsur mampu untuk berelaborasi dengan baik dalam rangka mengembangkan warisan budaya tradisional menuju ekowisata Dusun Giyanti.

\section{SIMPULAN}

Budaya yang diwariskan secara turun-temurun harus dilestarikan dengan sebaik mungkin. Hal ini dikarenakan budaya menunjukkan identitas suatu masyarakat. Salah satu warisan budaya yang terdapat di kabupaten Wonosobo ialah Tari Lengger yang kemudian menjadi kekhasan dari Dusun Giyanti karena dari dusun inilah melahirkan banyak lengger. Selain itu juga terdapat budaya Nyadran Tenongan sebagai salah satu wadah kegiatannya. Masyarakat di Dusun Giyanti mampu untuk melestarikan warisan tersebut bahkan mampu untuk mengembangkan model Community Based Tourism dan mengemas menjadi konsep yang apik berupa ekowisata. Hal yang disayangkan ialah pemerintah belum maksimal dalam menindaklanjuti program-program yang dapat mendukung orbitasi pariwisata. Oleh karena itu, besar harapannya ke depan dapat terjalin kolaborasi yang apik antara masyarakat dan pemerintah dalam rangka mengembangkan warisan budaya tradisional menuju ekowisata Dusun Giyanti.

\section{DAFTAR PUSTAKA}

Akbar, Al Nuruddin. 2016. "Menjinakkan" Globalisasi: Studi Kritis Globalisasi Budaya pada Pementasan Sendra Tari Ramayana Borobudur”. Jurnal Ilmu Sosial Mamangan, 5 (1), 1-12. http://ejournal.stkip-pgri-sumbar.ac.id/index.php/jurnal-mamangan 
Akbar, Syahrul dkk. 2019. "Wisuda Lengger Giyanti Sebagai Daya Tarik Wisata di Kabupaten Wonosobo". Journal of Sustainable Tourism Research, 1 (1), 22-30. http://jurnal.unpad.ac.id/tornare/article/view/25364

Aulia, Afifah Nur dan Luchman Hakim. 2017. "Pengembangan Potensi Ekowisata Sungai Pekalen Atas, Desa Ranu Gedang, Kecamatan Tiris, Kabupaten Probolinggo". Jurnal Wilayah dan Lingkungan, 5 (3), 156-167. , http://dx.doi.org/10.14710/jwl.5.3.156-167

Dinas Pariwisata dan Kebudayaan. 2017. Rencana Strategis Dinas Pariwisata dan Kebudayaan Wonosobo 2016-2021. Wonosobo: Dinas Pariwisata dan Kebudayaan

Endraswara, Suwardi. 2006. Metode, Teori, Teknik Penelitian Kebudayaan Ideologi, Epistemologi, dan Aplikasi. Yogyakarta: Pustaka Widyatama.

Herman, Nencyana Natalia dan Bambang Supriadi. 2017. "Potensi Ekowisata dan Kesejahteraan Masyarakat". Pesona, 2 (2), 1-12. http://jurnal.unmer.ac.id/index.php/jpp/article/view/1578/1141.

Hidayah, A. (2017). Makna Budaya Lagu Dolanan: Dhondhong Apa Salak, Gundhul Pacul. Jurnal Penelitian Humaniora, 18(1), 19-26.

Hijriati dan Rina. 2014. "Pengaruh Ekowisata Berbasis Masyarakat terhadap Perubahan Kondisi Ekologi, Sosial dan Ekonomi di Kampung Batusuhunan, Sukabumi”. Jurnal Sosiologi Pedesaan, 3 (2), 146-159. http://repository.ipb.ac.id/handle/123456789/66783

Mukhlisi. 2017. "Potensi Pengembangan Ekowisata Mangrove di Kampung Tanjung Batu, Kecamatan Pulau Derawan, Kabupaten Berau". Jurnal Manusia dan Lingkungan, 24 (1), 23-30. https://doi.org/10.22146/jml.22939.

Puspita dan Susi. 2016. "Strategi Pengelolaan Desa Wisata Giyanti, Kabupaten Wonosobo". Journal of Public Policy And Management Review. 5 (2). https://doi.org/10.14710/jppmr.v5i2.10697

Ratna, Nyoman Kutha. 2010. Metodologi Penelitian Kajian Budaya dan Ilmu Sosial Humaniora Pada Umumnya. Yogyakarta: Pustaka Pelajar.

Ridlwan, dkk. 2017. "Model Pengembangan Ekowisata dalam Upaya Pemberdayaan Masyarakat Lokal”. Politik Indonesia, 2 (2), 141-157. http://journal.unnes.ac.id/nju/index.php/JPI

Sudaryanto. 1993. Metode dan Aneka Teknik Analisis Bahasa. Yogyakarta: Duta Wacana University Press.

Sugiarta, Komang Agus dan I Gst Agung Oka Mahagangga. 2016. “Analisis Potensi Ekowisata dan Respon Masyarakat Desa Penijnoan Kecamatan Tembuku Kabupaten”. Jurnal Destinasi Pariwisata, 2 (4), 109-113. https://doi.org/10.24843/JDEPAR.2016.v04.i02.p19.

Tanaya, Dhayita Rukti dan Iwan. 2014. "Potensi Pengembangan Ekowisata Berbasis Masyarakat di Kawasan Rawa Pening, Kabupaten Semarang". Jurnal Teknik PWK, 1 (3), 71-81. http://ejournal-s1.undip.ac.id/index.php/pwk

Wahyudi. 2010. Kajian Kerja Sama Daerah dalam Pengelolaan dan Pengembangan Kawasan Wisata Dataran Tinggi Dieng [tesis]. Semarang (ID). Universitas Diponegoro. http://eprints.undip.ac.id/23708/. 